\title{
GALIJSKA KATASTROFA POD TELAMONEM W 225 ROKU P.N.E. - ASPEKT MILITARNO-PSYCHOLOGICZNY
}

\section{Bronisław Szubelak}

Brzeg

\section{ABSTRACT \\ THE GALLIC DISASTER AT TELAMON IN 225 BC: THE MILITARY AND PSYCHOLOGICAL ASPECT}

The Celtic tribes migrated into Northern Italy in the late $8^{\text {th }}$ and $7^{\text {th }}$ centuries BC. In 390 BC the Gauls sacked the city of Rome. The Romans believed that they would never be safe while the Gauls threatened their northern frontier, so they colonized the land in the northern part of Picenum in $232 \mathrm{BC}$. In $225 \mathrm{BC}$, a huge Gallic army swarmed southwards through Etruria. Some 50,000 infantry and 20,000 cavalry and chariots drawn from the Cisalpine Boii, Insubres, Taurisci and Transalpine Gaesatae plundered the region and annihilated the Roman forces at Clusium, 3 days of march north of Rome. At Telamon, however, they were intercepted by two Roman forces ( 8 legions and allies), approaching them from two opposite directions. The Gauls were forced to deploy their army facing both ways. The line facing rearward, anticipating Aemilius, had the Gaesatae in front and the Insubres behind them. Facing the opposite direction, ready to meet Atilius, were the Taurisci and Boii. Gaesatae (probably javeleeners) fought naked, standing proudly in front of the whole army with nothing but their weapons to protect them. The Insubres and Boii, by contrast, wore trousers and cloaks. The strength of a Gallic attack lay in the first onslaught, its power fuelled by the belief in a glorious afterlife, the desire for fame, and some hysteria fuelled by noise and chanting, and often enhanced by alcohol. Such charges lacked focus and, if repulsed, the Gauls had no strategy for recovery and became desperate. The Roman light infantry javelins inflicted heavy damage on the naked Gaesatae. The Roman maniples armed with a pila, a heavy javelin designed to penetrate the target's shield, and a gladius, a short stabbing sword, attacked the Insubres, Boii and Taurisci. The Gauls were finally defeated when they were attacked on their flank by the Roman cavalry. The Gallic infantry were cut to pieces, and the cavalry fled. Polybius reports that 40,000 Gauls were killed in the battle. The Battle of Telamon was the last recorded use of chariots in a battle on the European continent. During the $3^{\text {rd }}$ century BC, the cavalry became more significant in Gallic warfare. After this battle, Gallic cavalry would serve as mercenary troops for foreign armies.

Key words: chariots, Gaesatae, charge, naked, javelins.

Słowa kluczowe: rydwany, Gaesates, szarża, nadzy, oszczepy.

Adres do korespondencji: bszub9@gmail.com 
Zasiedlenie doliny Padu przez plemiona celtyckie, po długim okresie wymiany kulturowej i materialnej z ludami italskimi, nastąpiło prawdopodobnie między VIII a VII wiekiem p.n.e. Dokonało się stopniowo w wyniku kilku fal migracyjnych, oddzielonych od siebie dziesiątkami lat, kosztem ziem Etrusków ${ }^{1}$. Nowi mieszkańcy przybyli zza Alp - czyli plemiona Insubrów, Cenomanów, Bojów, Lingonów i Senonów - dali temu obszarowi nazwę Galia Cisalpina, wywodzącą się od nazwy własnej, tradycyjnie przypisanej tej grupie celtyckiej przez Rzymian. Ci ostatni szczególnie dotkliwie odczuli kłopotliwe sąsiedztwo w związku z całą serią najazdów pustoszących Lacjum w IV wieku p.n.e. Na trwałe w ich zbiorowej pamięci zapisała się katastrofalna klęska nad Allią w 390 roku p.n.e., zakończona zdobyciem Rzymu i dramatyczną obroną Kapitolu. Początek III wieku p.n.e. przyniósł pierwsze próby podboju terenów galijskich przez Rzym, jak w przypadku kolonii Sena Gallica utworzonej po spacyfikowaniu Senonów. Dalsze działania w tym kierunku zahamowała pierwsza wojna punicka, stabilizując sytuację na tym obszarze na niemal pół wieku. Ponowne zaostrzenie wzajemnych stosunków nastąpiło w wyniku decyzji senatu rzymskiego, który na wniosek Gajusza Flaminiusza w 232 roku p.n.e. wydzielił pod osadnictwo północną część Picenum, stanowiącą terytorium odebrane Senonom². Wywołało to falę niepokoju i doprowadziło do antyrzymskiego sojuszu szczególnie zagrożonych plemion Bojów i Insubrów. Biorąc pod uwagę szczupłość sił własnych, wyniszczonych w walkach zewnętrznych i wewnętrznych, zdecydowano o sprowadzeniu pomocy zza Alp. Wezwano wojowników z plemienia Taurysków i przekupiono złotem oraz obietnicą obfitych łupów tzw. Gaesatów. Zarówno u autorów antycznych, jak i we współczesnych opracowaniach brak jednoznacznego stanowiska w kwestii pochodzenia tychże oraz charakteru łączących ich więzi. Już sama nazwa gaesatae tłumaczona jest przez Polibiusza jako synonim najemnych żołnierzy i użycie w tym kontekście greckiego terminu hetairia na określenie relacji wewnątrz grupy rodzi wiele domysłów ${ }^{3}$. Mimo pojawiających się sugestii, że mamy do czynienia z plemieniem zamieszkującym dorzecze Rodanu, zdecydowana większość badaczy optuje za ponadplemiennym bractwem młodych wojowników o elitarnym charakterze, związanym przysięgą wierności z charyzmatycznymi przywódcami ${ }^{4}, \mathrm{w}$ tym konkretnym przypadku z dwoma królami - Aneroestem i Konkolitanem. Równie ciekawie przedstawia się etymologia słowa gaesatae wywodzona od gaiso, czyli włóczni (po łacinie gaesum lub geissi), odnoszącego się do więzów, tabu albo uświęconych zasad postępowania. Najbardziej rozpowszechnioną formą jest gaisatus, czyli 'wojownik uzbrojony we włócznię, włócznik's. Rzecz jednak w tym, że gaesum jako nazwa odnosi się nie do włóczni, ale do rodzaju oszczepu, a więc broni miotanej, zbliżonej

1 D. Kratzer, The Gaesates, Ancient Warfare VII, 3, s. 48; A. Grenier, Historia Galów, thum.

A. Delahaye, M. Hoffman, Gdańsk-Warszawa 2002, s. 83.

2 Polib. II, 19-21.

3 Ibidem, II, 22; F. Mathieu, Le guerrier gaulois, Paris 2012, s. 88-89.

4 D. Ó hÓgáin, Celtowie, tłum. M. Zwoliński, Warszawa 2009, s. 56; D. Kratzer, op. cit., s. 52.

5 S. Allen, Celtic Warriors 300 BC-AD 100, Oxford 2001, s. 14-15; D. Kratzer, op. cit., s. 49;

P. Harrison, Great Battles of the Ancient World, London 2004, s. 52. 
formą i funkcją do rzymskiego pilum ${ }^{6}$. Gaesati to zatem oszczepnicy, którzy w masie zasilili szeregi armii plemiennych, liczących teraz 50000 wojowników pieszych i 20000 konnicy, złożonej z kawalerii, ale głównie - jak się wydaje - z rydwanów bojowych, nieco już archaicznych dwukołowych wozów o stosunkowo lekkiej konstrukcji, zaprzężonych w dwa konie, z woźnicą i uzbrojonym jak piechur wojownikiem na platformie. Rolą rydwanu było dowiezienie wojownika na miejsce boju, gdzie podejmował walkę pieszo, a w przypadku niepowodzenia - umożliwienie mu natychmiastowej ewakuacji ${ }^{7}$. Kawaleria to głównie znakomicie wyekwipowani przedstawiciele arystokracji plemiennej i być może gwardia osobista królów, określana mianem soldurii, związana więzami klientelnymi, przypieczętowanymi przysięgą, i umierająca wraz z władcami ${ }^{8}$.

Tumultus gallicus, jak w annałach rzymskich nazwano te wydarzenia, wywołał w społeczeństwie rzymskim prawdziwą psychozę, której podłożem mogła być wspomniana obawa o miasto Rzym, jak też liczebność nadciągających barbarzyńców. To zaś spowodowało pełną mobilizację sił i środków. Polibiusz podaje, że każdy konsul otrzymał pod komendę 4 legiony, a w każdym 5200 pieszych i 300 jeźdźców oraz 32000 sprzymierzeńców jako wsparcie ${ }^{9}$. Oprócz tego sformowano armię złożoną z 54000 Sabinów i Etrusków pod dowództwem pretora. Znaczne siły zgromadzono w Rzymie, wezwano resztę sprzymierzeńców do przysłania kontyngentów zbrojnych i obstawiono drogi prowadzące do miast. Wreszcie przeciągnięto na swoją stronę plemiona Wenetów i celtyckich Cenomanów, a ich licząca 20000 ludzi armia, wraz z równą im siłą armią Umbrów i Sarsynatów, miała zaatakować Bojów na ich własnym terytorium.

Mimo konieczności oddelegowania konsula Gajusza Atyliusza Regulusa z jego żołnierzami na Sardynię w celu stłumienia tamtejszej rewolty suma wojsk, które dla ochrony Rzymu stały w polu, wynosiła ponad 150000 pieszych i około 6000 jeźdźców. Łącznie zmobilizowano ponad 250000 wojowników i 23000 konnicy z 770000 rezerwy ludzkiej, jaką dysponowała w tym czasie Republika Rzymska ${ }^{10}$.

6 G. Canestrelli, I Celti e l'arte della Guerra, Citta di Castello 2010, s. 173, oszczep wykonany w całości z metalu, z grotem w kształcie harpuna, popularny u Celtyberów; D. Ó hÓgáin, op. cit., s. 56; A. Deyber, Les Gaulois en guerre, Paris 2009, s. 306-307, nazwa oszczepu wykonanego z metalu, przypominającego kształtem pilum rzymskie, urobiona od Gaesatów; F. Quesada Sanz, La evolucion de la panoplia y de las tacticas galas, Desperta Ferro II, 2, s. 21, oszczep z wąską penetrującą końcówką, miotany na dystansie do $30 \mathrm{~m}$.

7 Diod. V, 29,1; P. Harrison, op. cit., s. 51; R.A. Gabrie1, The Great Armies of Antiquity, Westport-London 2002, s. 262; B. Cunliffe, Starożytni Celtowie, thum. E. Klekot, Warszawa 2003, s. 125.

8 A. Grenier, op. cit., s. 156; Caes. bell. gall. III, 22; F. Schlette, Celtowie, thum. S. Lisicka, B. Wierzbicka, Łódź 1987, s. 112.

9 Polib. II, 24, niejasny przekład Hammera sugeruje, że obaj konsulowie mieli pod bronią łącznie 4 legiony i 32000 sprzymierzeńców, kiedy w oryginale to jedna armia konsularna, a były dwie; M. Dobson, The Army of the Roman Republic, Oxford 2008, s. 56. Łączone działania dwóch armii konsularnych w sile 4 legionów ze sprzymierzeńcami były normą w okresie między pierwszą a drugą wojną punicką, z wyjątkiem zagrożenia najazdem galijskim w 225 r. p.n.e., kiedy każdy z konsulów dowodził 4 legionami.

10 Polib. II, 24; A.S. Bradford, With Arrow, Sword and Spear, Westport-London 2001, s. 177. 
W ramach przygotowań do odparcia inwazji dyslokowano drugą armię konsularną Lucjusza Emiliusza Papusa w Ariminum (Rimini), na pograniczu galijskim, a siły pretora skoncentrowano pod Arretium, w Etrurii ${ }^{11}$.

Galowie od północy wkroczyli do Etrurii i łupiąc ją bezlitośnie, maszerowali na południe. Tak dotarli w okolice Clusium (Chiusi), odległego od Rzymu o trzy dni marszu. Kiedy doszły ich słuchy o nadchodzącej armii pretora, zawrócili na jej spotkanie i z uwagi na zmierzch rozbili obóz, prawdopodobnie koło miejscowości Kalousion (Doganella). W nocy piechota galijska niepostrzeżenie wymaszerowała drogą do Faesulae (Fiesole) i urządziła zasadzkę w niedużej odległości od miasta, pozostawiając jazdę jako przynętę. Rano konnica galijska ruszyła w kierunku przygotowanej zasadzki, wciągając w nią Rzymian, którzy w wyniku zaskoczenia stracili 6000 żołnierzy i wycofali się w panice na okoliczne wzgórze ${ }^{12}$. Tutaj, otoczeni przez przeważające siły, doczekali następnego dnia nadejścia konsula Lucjusza Emiliusza Papusa, który włączył ocalałych do swej armii.

Informacja o armii konsularnej zmusiła wodzów galijskich do zmiany planów. Na wniosek Aneroesta zdecydowano eskortować wzięte w Etrurii łupy do Galii Przedalpejskiej, by następnie wrócić i rozprawić się ostatecznie z Rzymianami ${ }^{13}$. W tym celu skręcono na północ, aby przemaszerować wzdłuż wybrzeża, nie zdając sobie sprawy, że konsul Gajusz Atyliusz Regulus powrócił jako zwycięzca z Sardynii, wyokrętował swe legiony w Portus Pisanus (Piza) i podążył na południe, w kierunku Rzymu, docierając w okolice Telamonu. Tutaj, chwytając zwiadowców galijskich, zorientował się w sytuacji strategicznej, nakazując legionom rozwinąć szyk i maszerować naprzód, sam zaś z kawalerią postanowił zająć znajdujące się niedaleko jego prawej flanki wzniesienie, przy drodze potencjalnego przemarszu wroga.

Galowie - przekonani, że to konnica ścigającej armii obchodzi ich pozycje - wysłali w celu opanowania strategicznego wzgórza swoją jazdę wspartą niewielkim oddziałem lekkozbrojnych, rychło jednak zorientowali się w sytuacji i podzielili piechotę na dwa fronty. Przeciwko ścigającemu ich z południowego wschodu Papusowi ustawili Gaesatów, a za nimi Insubrów, zaś przeciw nadchodzącemu z północnego zachodu Regulusowi zgrupowali Bojów i Taurysków w jednej linii. Każdy z szyków był flankowany przez wozy taborowe i rydwany ${ }^{14}$. Równocześnie całą zdobycz odesłali pod eskortą na nieodległe wzgórze Sugherino, leżące na północny wschód od uszykowanej do walki armii.

Papus także sprawił szyki, gotując się do starcia, lecz własną konnicę wysłał na wzgórze z pomocą Regulusowi ${ }^{15}$. Nie wiemy, jakimi siłami dysponował, ale jeżeli przyjąć, że dowodził 4 legionami, to musiał mieć około 1200 jeźdźców oraz 3600 jazdy sprzymierzonej, czyli łącznie 4800 kawalerzystów. Konnica rzymska

11 Polib. II, 23. W przypadku pretora dowodzącego siłami skoncentrowanymi pod Arretium chodzi zapewne o urzędnika nazywanego praetor peregrinus; G. della Monaca, Talamone 225 a.C., La battaglia dimenticata, Arcidosso 2012, s. 124-125.

12 Polib. II, 25; G. della Monaca, op. cit., s. 127-129.

13 Polib. II, 26.

14 Ibidem, II, 27.

15 Ibidem, II, 28. 
w tamtym okresie nie słynęła z bitności, ale nader często walczyła pieszo, co mogło być decydującym czynnikiem w bitwie o wzgórze ${ }^{16}$.

Ogląd domniemanego pola bitwy skłonił Gualtiero della Monaca do stwierdzenia, że konnica stoczyła walkę między wzgórzami, zwanymi dziś Civitella i Ospedaletto, a jeźdźcy galijscy, podobnie jak piechota, znaleźli się między atakującą konnicą Regulusa a nadciągającą kawalerią Papusa. Zmuszeni do ucieczki, przebili się, objeżdżając w prawo północne zbocze Ospedaletto, przed frontem jazdy Regulusa, i dotarli w pobliże szyku Taurysków i Bojów ${ }^{17}$. Niejako przy okazji w tej potyczce zginął z bronią w ręku konsul Regulus, a jego głowa jako trofeum została przekazana królom. Nie przeszkodziło to jednak Rzymianom odnieść zwycięstwa, dzięki - jak można mniemać - miażdżącej przewadze liczebnej.

Starcie wojsk pieszych opisane przez Polibiusza wygląda co najmniej dziwnie, a nawet niewiarygodnie. Należy się zgodzić z Delbrückiem, który kwestionuje prawdziwość przekazu źródłowego. Argumentuje, że Polibiusz opierał się na relacji Fabiusza Piktora, lecz miał mętne pojęcie o podboju Galii Przedalpejskiej ${ }^{18}$. Faktem jest, że tłumaczenie nagości Gaesatów w walce próżnością i butą oraz obawą przed cierniami świadczy o nieznajomości rzeczy. Diodor, opisując zwyczaje Celtów, wspomina, iż „niektórzy z nich gardzą śmiercią do tego stopnia, że wychodzą naprzeciw niebezpieczeństwu bitwy bez zbroi ochronnej i jedynie w pasie na biodrach" 19 . Współcześni autorzy wskazują na rytualny charakter nagości, choć jej sensu Galowie już nie rozumieli, bądź oznakę przynależności do elitarnej formacji bojowej, czy też zwyczaj najemników odwołujących się do boskiej protekcji ${ }^{20}$.

Bogów zaś na pole bitwy sprowadzały: wrzawa, dęcie w trąby zwane carnyx, rogi, łomot broni o tarcze, krzyk, a w końcu pieśń wojenna dobywająca się z tysięcy gardeł. Wszystko to było elementem swoistej walki psychologicznej, mającej doprowadzić do zastraszenia przeciwnika ${ }^{21}$. Już sam wygląd wysokich, muskularnych mężczyzn z obnażonymi torsami i ciałami pokrytymi tatuażami, ozdobionymi naramiennikami, bransoletami, z nieodłącznym symbolem wojowników celtyckich w postaci naszyjnika zwanego torques, robił na Rzymianach silne wrażenie ${ }^{22}$.

Starcie zbrojne zainicjowali rzymscy lekkozbrojni welici, obrzucając Galów lekkimi oszczepami, które największe szkody wyrządziły nagim Gaesatom, bo pozostałych, jak naiwnie podaje Polibiusz, chroniły płaszcze wojskowe i spodnie ${ }^{23}$. Pomijając kwestię fatalnego polskiego przekładu, a szczególnie brak znajomości terminologii odnoszącej się do wojskowości antycznej u Hammera, warto zwrócić uwagę na

16 Liv. III, 62: K.R. Dixon, P. Southern, Kawaleria rzymska, thum. P. Grysztar, Oświęcim 2012, s. 26; E. Razin, Historia sztuki wojennej, t. 1, thum. I. Bukowski, Warszawa 1958.

17 G. della Monaca, op. cit., s. 135-136.

18 H. Delbruck, Antyczna sztuka wojenna, t. 2: Republika Rzymska, thum. P. Grysztar, Oświęcim 2013, s. 59.

19 Diod. V, 29, 2.

20 Polib. II, 28; Liv. XXXVIII, 21; D. Ó hÓgáin, op. cit., s. 57; B. Cunliffe, op. cit., s. 123;

D. Kratzer, op. cit., s. 49; S. Allen, Celtic Warriors..., s. 27; P. Harrison, op. cit., s. 52.

21 Liv. XXXVIII, 17; B. Cunliffe, op. cit., s. 128.

22 P. Harrison, op. cit., s. 56.

23 Polib. II, 30. 
nowy sposób wojowania Rzymian. Po 390 roku p.n.e. obserwujemy głębokie zmiany w wojskowości rzymskiej, określane mianem reformy Kamillusa: falangę typu greckiego zastąpiono legionem manipularnym, wyposażonym w wielkie owalne tarcze italskie scuta oraz - w miejsce włóczni hastae - oszczepy pilae. Pilum to ciężki oszczep, który w okresie wojen samnickich uległ modyfikacji polegającej na skróceniu trzpienia grotu, lepszym wyważeniu broni i zwiększeniu penetracji. Masowe użycie oszczepu przez legionistów wymagało większej przestrzeni, a co za tym idzie - rozluźnienia szyku² ${ }^{24}$.

Następnym krokiem było ukształtowanie się tak zwanego legionu Polibiusza, łączącego taktykę lekkozbrojnej i ciężkozbrojnej piechoty, pozwalającą zdezorganizować szyk wroga gradem pilów tuż przed uderzeniem czołowym. Umiejętność luzowania walczących przez świeże siły, a przede wszystkim szkolenie legionistów w przyjmowaniu ciosów na tarczę i wyprowadzaniu krótkich pchnięć mieczem zza tarczy przeciw słabo opancerzonym barbarzyńcom były śmiertelnie skuteczne ${ }^{25}$.

Widać to wyraźnie w opisie bitwy pod Telamonem, kiedy sprowokowani lawiną pocisków Gaesaci albo rzucali się w samobójczym ataku na rzymski szyk, albo podawali tyły, mieszając własne szyki i siejąc panikę, jak relacjonuje Polibiusz. To bardzo charakterystyczny rys celtyckiej sztuki wojennej, preferującej gwałtowny atak, chaotyczny i nieprzemyślany, który w momencie załamania się, wpędzał wojowników w desperację, a jej owocem było heroiczne męstwo lub tchórzliwa ucieczka ${ }^{26}$. Siła ataku kumulowała się w pierwszym uderzeniu napędzanym dziką determinacją (wynikającą być może z wiary w życie pozagrobowe i nieśmiertelność duszy), żądzą sławy, a nawet histerią podsycaną wrzawą bojową i spożyciem alkoholu, jak twierdzi Cunliffe ${ }^{27}$.

Rzymski sposób walki miał wszelkie cechy sztuki wojennej, opartej na wyszkoleniu i dyscyplinie, w szczególności zaś na zachowaniu zimnej krwi w obliczu nieprzyjaciela. W fazie walki wręcz prosty i efektywny sposób posługiwania się mieczem służył szybkiej eliminacji wroga ${ }^{28}$.

Tak też przedstawia to Polibiusz, podając, iż Galowie zostali wycięci w bezpośrednim zwarciu, a klęski dopełnił atak konnicy rzymskiej z flanki, który zmusił jazdę wroga do ucieczki z pola bitwy, doprowadzając do wyrżnięcia piechoty na miejscu ${ }^{29}$.

24 R.L. O'Connell, Of Arms and Men, New York-Oxford 1989, s. 74; H.M.D. Parker, Legiony rzymskie, tłum. K. Narloch, Oświęcim 2013, s. 12-13, 16.

25 B.T. Carey, Ostatnia bitwa Hannibala, tłum. B. Waligórska-Olejniczak, Warszawa 2010, s. $41-42$.

26 Polib. II, 30; Liv. XXXVIII, 21, „...gdy z ukrycia i z daleka odnoszą rany od pocisków lekkozbrojnych formacji i nie mają się na kogo rzucić, w ślepej wściekłości wpadają na oślep na swoich, niczym trafiony pociskiem dziki zwierz"; B. Cunliffe, op. cit., s. 129; G. Kazakewicz, Wijskowi tradicii dawnich Keltiw na ziemlach Ukraini IV-I st. do n.e., Kiiw 2008, s. 25; N. Sekunda, Republican Roman Army 200-104 BC, Oxford 1996, s. 35, zamiana hastae na pilum nastąpiła w połowie III w. p.n.e.

27 B. Cunliffe, op. cit., s. 129.

28 N. Fields, Roman Republican Legionary 298-105 BC, Oxford 2012, s. 57; R.L. O’Connell, op. cit., s. 73.

29 Polib. II, 30. 
Jako przyczynę tak miażdżącego zwycięstwa, mimo ewidentnego męstwa Galów, autor podaje nieskuteczność broni stosowanej przez wojowników, przede wszystkim tarcz, które w jego przekonaniu nie osłaniają należycie ciała, w przeciwieństwie do rzymskiego scutum, ponieważ są mniejsze. I z tym należałoby się zgodzić, idąc za Liwiuszem charakteryzującym tarcze Galatów jako „za mało szerokie, a przy tym płaskie" ${ }^{30}$. Chociaż warto zauważyć, że Celtowie tak jak Rzymianie przyjęli ten rodzaj osłony ciała $z$ terenu północnej Italii. Tam w VIII wieku p.n.e. dominował typ określany jako thureos o owalnym obrysie przypominającym nieco drzwi, który szczególnie od III wieku p.n.e. chętnie przyjmowały do uzbrojenia armie śródziemnomorskie. Wykonywano go z dwóch drewnianych połówek, łączonych pionowo, a styk zabezpieczano czy też chowano pod wrzecionowatą listwą zwaną spinae, na którą nabijano w centralnej części metalowe umbo, często ze skrzydełkami ${ }^{31}$. Miało ono przede wszystkim osłonić znajdujący się pod nim żelazny imacz. Podstawowym mankamentem konstrukcji było to, że mogła zostać rozcięta na pół dobrze ukierunkowanym ciosem miecza, co czyniło żołnierza bezbronnym ${ }^{32}$. Aby temu zaradzić, zarówno Celtowie, jak i Rzymianie okuwali górny i dolny brzeg tarczy brązową lub żelazną listwą w kształcie rynienki ${ }^{33}$. Istotnym elementem różniącym te dwie tarcze było sferyczne wygięcie rzymskiej, znakomicie poprawiające osłonę ciała oraz solidność samej konstrukcji. Widać to najlepiej na przykładzie wagi: galijska ważyła 5-7 kilogramów, a rzymska - 10 kilogramów. Wskazuje to na większą wrażliwość tej pierwszej, na jej podatność na perforację, w szczególności przez miotane pociski ${ }^{34}$.

Drugim rodzajem broni, który całkowicie zawiódł podczas walki, był prosty i długi miecz obosieczny, w terminologii bronioznawczej nazywany lateńskim, a u Celtów prawdopodobnie cladios, od którego to określenia zapewne pochodzi rzymska forma gladius $^{35}$. Według Polibiusza klingi były tak kiepskiej jakości, że już po pierwszym ciosie ulegały odkształceniu i trzeba je było doginać nogą. Ponadto szczerbiły się, a tępy sztych sprawiał, iż można było użyć miecza wyłącznie jako broni siecznej ${ }^{36}$. Co gorsza, z tekstu wynika, że każdy wojownik galijski był uzbrojony w miecz jako główny oręż do walki wręcz. Jakby tego było mało, autorzy antyczni ganią Celtów za nieumiejętne posługiwanie się mieczem. Dionizjos pisze: ,już to wznosząc wysoko swoje miecze, uderzali ślepo, z dziką siłą, jak drwale, już to wywijali bronią, próbując zadać cios z boku, jakby zamierzali za jednym zamachem przepołowić ciało wroga, a tylko szczerbili ostrza”. I równocześnie prezentuje rzymską szkołę walki polegającą na tym, że „gdy Gal podnosił broń, Rzymianin wsuwał mu się pod ramię, pochylał i podniósłszy wysoko tarczę, powodował, że wymierzony cios stawał się

30 Ibidem; Liv. XXXVIII, 21.

31 F. Quesada Sanz, op. cit., s. 21.

32 N. Fields, Roman Battle Tactics 390-110 BC, Oxford 2010, s. 45.

33 A. Grenier, op. cit., s. 141; P. Meyer, Vae victis, Ancient Warfare VI, 6, s. 26; B. Cunliffe, op. cit., s. 121.

34 F. Quesada Sanz, op. cit., s. 21.

35 A. Deyber, op. cit., s. 297; G. Banfi, L'Armamento dei Celti, Rimini 2004, s. 34, twierdzi, że słowo gladius ma celtyckie pochodzenie.

36 Polib. II, 30, 33. 
nieskuteczny”. Następnie „godził Gala w bok lub pierś i sięgał wnętrzności. Jeżeli wróg osłaniał tę część ciała, podcinał mu kolana albo pęciny i Gal padał na ziemię, straszliwie wrzeszcząc i wbijając zęby w tarczę" ${ }^{37}$. Jakkolwiek sam opis wydaje się całkowicie wiarygodny, bo potwierdzony przez Liwiusza czy Plutarcha ${ }^{38}$, to wątpliwości rodzi kilka kwestii, takich jak dostępność tego typu oręża, jego jakość czy wyłącznie sieczny charakter.

Mało prawdopodobne jest uznanie miecza za podstawowy element wyposażenia wszystkich wojowników galijskich w tamtym okresie. Ten typ uzbrojenia miał charakter elitarny, co poświadczają odkrycia archeologiczne pochówków datowanych na 400 rok p.n.e. - tylko w co dziesiątym na tysiąc przebadanych występował miecz. Świadczy to o wąskim gronie użytkowników, szacowanym na $10-15 \%$, wywodzących się z arystokracji plemiennej i grupy bogatych wojowników ${ }^{39}$. W III wieku p.n.e., w związku z popularyzacją rzemiosła wojennego wśród średniozamożnej warstwy, służącej jako żołnierze najemni, zwiększyła się zapewne rzesza szermierzy, maksymalnie do $20 \%$ ogólu $^{40}$. Nie dotyczyło to jednak Gaesati, którzy jako bractwo wojenne tworzyli grupę zawodowych wojowników i w ich najlepiej rozumianym interesie własnym leżało dozbrojenie się w miecze. Tym bardziej że już od V wieku p.n.e., w związku z eskalacją dynamizmu i mobilności celtyckich ugrupowań bojowych na polu bitwy, odrzucono ciężki ekwipunek, organizując grupy uderzeniowe złożone z szermierzy wykorzystujących przewagę wzrostu i preferujących cięcia wyprowadzane $\mathrm{z}$ góry ${ }^{41}$. Rozwiązano też podstawowy problem, jakim była metalowa pochwa, przeszkadzająca w biegu, poprzez zaprojektowanie funkcjonalnego troczenia z użyciem pasa skórzanego, pierścienia i metalowego łańcucha, utrzymujących pochwę z mieczem pionowo lub lekko pod kątem na prawym udzie ${ }^{42}$.

Jakość kling to pochodna stopnia rozwoju metalurgii na obszarach osadnictwa celtyckiego, umiejętności samych kowali oraz oczekiwań i zasobności odbiorców. Luksusowe egzemplarze $\mathrm{z}$ damastu skuwanego trafiały w ręce arystokracji walczącej na rydwanach lub konno, reszta musiała się zadowolić tanimi mieczami o bardzo ograniczonej żywotności. Badania metalurgiczne wskazują, że nawet $40 \%$ zachowanych egzemplarzy zaopatrzono w niskiej jakości brzeszczot ${ }^{43}$. Być może ma to związek z kuciem kling z żelaza o niskiej zawartości węgla (tzw. prymitywnej stali) i brakiem umiejętności hartowania ich w cieczy, co w rezultacie dawało niewielką

37 Dion. Hal. XIV, 9.

38 Liv. XXII, 46; Plut. Cam. 41, 5.

39 P. Meyer, op. cit., s. 26-27.

40 L. Rawling s, Celtic and Iberian Warrior Cultures [w:] The Ancient World at War, ed. P. de Souza, London 2008, s. 168.

${ }_{41}$ P. Connolly, The Early Roman Army [w:] Warfare in the Ancient World, ed. J. Hackett, London 1989, s. 138; A. Blumberg, In the Service of Carthage, Ancient Warfare VI, 6, s. 24; G. Canestrelli, op. cit., s. 29; G. Kazakewicz, op. cit., s. 26.

42 F. Mathieu, op. cit., s. 62; G. Canestrelli, op. cit., s. 79; F. Quesada Sanz, op. cit., s. 22; P. Wilcox, Rome's Enemies: Gallic and British Celts, Oxford 1985, s. 21; B. Cunliffe, op. cit., s. 130.

43 F. Quesada Sanz, op. cit., s. 22. 
sprężystość, w związku z czym miecze nie łamały się, lecz gięły ${ }^{44}$. Innym wytłumaczeniem może być zastosowanie starożytnej techniki hartowania samych ostrzy w wilgotnej ziemi przez ruchy posuwisto-zwrotne, określanej jako „kalanie”. Jeszcze inną metodą praktykowaną $\mathrm{w}$ tamtym okresie było kucie na zimno mieczy o zawartości węgla poniżej $0,1 \%$, niedających się utwardzić przez hartowanie. Była to obróbka wykańczająca (podobna do klepania kosy) głowni ostrych i sprężystych, wykazujących ugięcie do 15 centymetrów i zdolność do rąbania twardego drewna, a nawet kości, bez wyraźnego uszczerbku, jak wykazały przeprowadzone eksperymenty ${ }^{45}$. Jedynym wyjaśnieniem lichej jakości mieczy galijskich, w tym wypadku, jest zatem teoria wskazująca na powiązanie z obrządkiem grzebalnym u Celtów, podczas którego dochodziło do rytualnego zabójstwa miecza zmarłego poprzez wyżarzenie w ogniu, a następnie kilkukrotne zgięcie lub złamanie ${ }^{46}$. Ewentualnie można się też pokusić o stwierdzenie, że skoro miecz lateński nie był bronią do finezyjnej szermierki, lecz do posiekania wroga na kawałki, to mocne ciosy wyprowadzane z góry na tarczę czy hełm mogły powodować jego uszkodzenie, co zdaje się potwierdzać Dionizjos ${ }^{47}$.

Całkowicie niezrozumiałe jest natomiast twierdzenie o braku ostrego sztychu u miecza piechoty. Co więcej, nie znajduje ono odzwierciedlenia w materiale archeologicznym. W ostatniej ćwierci III wieku p.n.e. nadal dominowała broń sieczno-kłująca z ostrym sztychem, klasyfikowana jako typ Hatvan-Boldog. Już na początku wieku zanikały najdłuższe i najkrótsze egzemplarze, a pozycję dominującą zajął średni miecz z głownią mierzącą około 60 centymetrów długości i 4 centymetry szerokości ${ }^{48}$. Idealna broń dla piechoty, ale także dla wojowników dowożonych rydwanami i być może kawalerii. Oczywiście termin „długi miecz” jest w tym wypadku umowny, chyba że równolegle funkcjonował dłuższy z tępym sztychem jako uzbrojenie kawalerii, lecz całkowicie nieprzydatny dla pieszych wojowników, jak sugerują znawcy problematyki ${ }^{49}$. Jedynym rozsądnym wytłumaczeniem rewelacji Polibiusza może być przeniesienie realiów nieco późniejszych do opisywanego okresu i wydarzeń, których naocznym świadkiem bez wątpienia nie by ${ }^{50}$.

Bitwa pod Telamonem miała kluczowe znaczenie dla podboju Galii Przedalpejskiej i słusznie określona została przez Gualtiero della Monaca jako la battaglia dimenticata, czyli zapomniana bitwa. Rozmiar klęski galijskiej: 40000 poległych i samobójcza śmierć króla Aneroesta oraz niewola 10000 wojowników i króla Konkolitana, to przykład świetnego zwycięstwa, choć okupionego zapewne sporymi stratami po stronie rzymskiej. Należy jednak pamiętać, że mamy do czynienia

44 M. Loades, Swords and Swordsmen, Barnsley 2010, s. 48; A. Cremin, Celtowie, thum. P. Szymor, Warszawa 2001, s. 47; W. Wojciechowski, Broń pierwotna i starożytna w Polsce, Warszawa 1973, s. 165.

45 W. Sławiński, Techniki kowalskie stosowane na Mazowszu w okresie wpływów rzymskich, http://www.platnerz.com/ [dostęp: 10.09.2015].

46 S. Allen, Lords of Battle, Oxford 2007, s. 117.

47 Dion. Hal. XIV, 10; N. Fields, Roman Republican Legionary..., s. 56.

48 G. Canestrelli, op. cit., s. 76-77; F. Quesada Sanz, op. cit., s. 22.

49 S. Allen, Lords of Battle, s. 46; B. Cunliffe, op. cit., s. 131.

50 A. Deyber, op. cit., s. 297. 
z klasycznym konfliktem asymetrycznym, i to przynajmniej w dwóch aspektach. Pierwszy to przygniatająca przewaga liczebna Rzymian, wynikająca $\mathrm{z}$ wielkości użytych sił i szeroko zakrojonej mobilizacji rezerw ludzkich. Ten schemat działania powtórzy się w okresie drugiej wojny punickiej i mimo kilku spektakularnych niepowodzeń przyniesie Rzymowi upragnione zwycięstwo. Drugi aspekt to konfrontacja dwóch różnych systemów militarnych preferujących odmienne style wojowania. Galowie, opierający siłę zbrojną na armiach plemiennych, mało zdyscyplinowanych, dowodzonych kolegialnie bez głębszej znajomości taktyki i współdziałania między rodzajami broni, prezentują archaiczny system wojskowy. Rzymianie wręcz przeciwnie: dzięki odejściu od falangi w stylu greckim i wykształceniu legionu manipularnego z jego specyficzną taktyką walki prezentują wyrafinowany model organizacji wojskowej. Indywidualizmowi celtyckiemu, przejawiającemu się męstwem, pogardą śmierci czy rezygnacją z kompleksowej ochrony ciała strona rzymska przeciwstawia walkę zespołową, dyscyplinę i rozbudowany arsenał uzbrojenia.

Ubocznym skutkiem tej batalii będzie całkowite wyeliminowanie z użycia na kontynencie europejskim, poza Brytanią, rydwanów bojowych i gwałtowny wzrost roli kawalerii $w$ armiach plemiennych. Wiązała się z tym ewolucja miecza lateńskiego, a właściwie koegzystencja dwóch jego odmian: krótszej sieczno-kłującej z ostrym sztychem dla piechoty, i dłuższej, siecznej z tępym sztychem, dla jazdy. Konnica galijska jako kontyngenty najemne pojawi się, bezpośrednio po bitwie pod Telamonem, w wielu armiach basenu Morza Śródziemnego.

\section{BIBLIOGRAFIA}

\section{Źródła}

Diodorus Siculus, Bibliotheca Historica I-V, ed. I. Bekker, L. Dindorf, F. Vogel, Teubner 1888-1890.

Dionysi Halicarnasensis, Antiquitatum Romanorum, ed. C. Jacoby, Teubner 1885-1925. Gajusz Juliusz Cezar, Wojna galijska, tłum. E. Konik, Ossolineum 1978.

Plutarch z Cheronei, Żywoty równoległe, t. II, tłum. K. Korus, L. Trzcionkowski, Warszawa 2005.

Polibiusz, Dzieje, t. I, thum. S. Hammer, Wrocław 1957.

Polybius, Historiae, ed. L. Dindorf, Teubner 1882.

Tytus Liwiusz, Dzieje Rzymu od założenia miasta, tłum. A. Kościółek, M. Brożek, Ossolineum 1968-1982.

\section{Opracowania}

Allen S., Celtic Warriors 300 BC-AD 100, Oxford 2001.

Allen S., Lords of Battle, Oxford 2007. 
Banfi G., L'Armamento dei Celti, Rimini 2004.

Blumberg A., In the Service of Carthage, Ancient Warfare VI,6.

Bradford A.S., With Arrow, Sword and Spear, Westport-London 2001.

Canestrelli G., I Celti e l'arte della guerra, Citta di Castello 2010.

Carey B.T., Ostatnia bitwa Hannibala, tłum. B. Waligórska-Olejniczak, Warszawa 2010.

Connolly P., The Early Roman Army [w:] Warfare in the Ancient World, ed. J. Hackett, London 1989.

Cremin A., Celtowie, thum. P. Szymor, Warszawa 2001.

Cunliffe B., Starożytni Celtowie, tłum. E. Klekot, Warszawa 2003.

Delbruck H., Antyczna sztuka wojenna, t. 2: Republika Rzymska, tłum. P. Grysztar, Oświęcim 2013.

Deyber A., Les Gaulois en guerre, Paris 2009.

Dix on K., Southern P., Kawaleria rzymska, tłum. P. Grysztar, Oświęcim 2012.

Dobson M., The Army of the Roman Republic, Oxford 2008.

Fields N., Roman Battle Tactics 390-110 BC, Oxford 2010.

Fields N., Roman Republican Legionary 298-105 BC, Oxford 2012.

Gabriel R.A., The Great Armies of Antiquity, Westport-London 2002.

Grenier A., Historia Galów, thum. A. Delahaye, M. Hoffman, Gdańsk-Warszawa 2002.

Harrison P., Great Battles of the Ancient World, London 2004.

Kazakewicz G., Wijskowi tradicii dawnich Keltiw na ziemlach Ukraini IV-I st. do n.e., Kiiw 2008.

Kratzer D., The Gaesates, Ancient Warfare VII,3.

Loades M., Swords and Swordsmen, Barnsley 2010.

Mathieu F., Le guerrier gaulois, Paris 2012.

Meyer P., Vae victis, Ancient Warfare VI,6.

Monaca della G., Talamone 225 a.C., La battaglia dimenticata, Arcidosso 2012.

O'Connell R.L., Of Arms and Men, New York-Oxford 1989.

Ó hÓgáin D., Celtowie, tłum. M. Zwoliński, Warszawa 2009.

Parker H.M.D., Legiony rzymskie, tłum. K. Narloch, Oświęcim 2013.

Quesada Sanz F., La evolucion de la panoplia y de las tacticas galas, Desperta Ferro II,2.

Rawlings L., Celtic and Iberian Warrior Cultures [w:] The Ancient World at War, ed. P. de Souza, London 2008.

Razin E., Historia sztuki wojennej, t. 1, tłum. I. Bukowski, Warszawa 1958.

Schlette F., Celtowie, tłum. S. Lisicka, B. Wierzbicka, Łódź 1987.

Sekunda N., Republican Roman Army 200-104 BC, Oxford 1996.

Sławiński W., Techniki kowalskie stosowane na Mazowszu w okresie wpływów rzymskich, http://www.platnerz.com/ [dostęp:10.09.2015].

Wilcox P., Rome's Enemies: Gallic and British Celts, Oxford 1985.

Wileman J., Warfare in Northern Europe before the Romans, Barnsley 2014.

Wojciechowski W., Broń pierwotna i starożytna w Polsce, Warszawa 1973. 


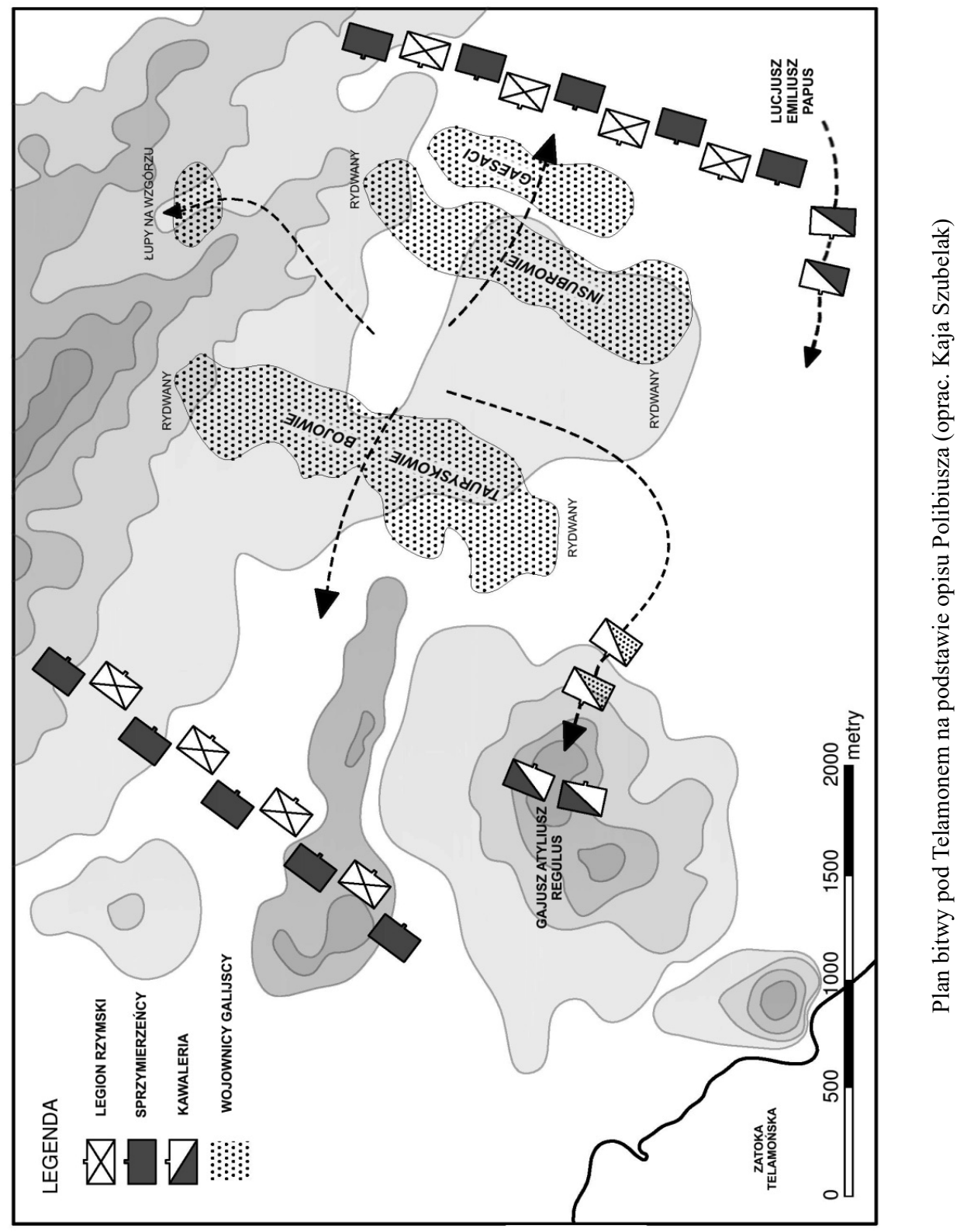




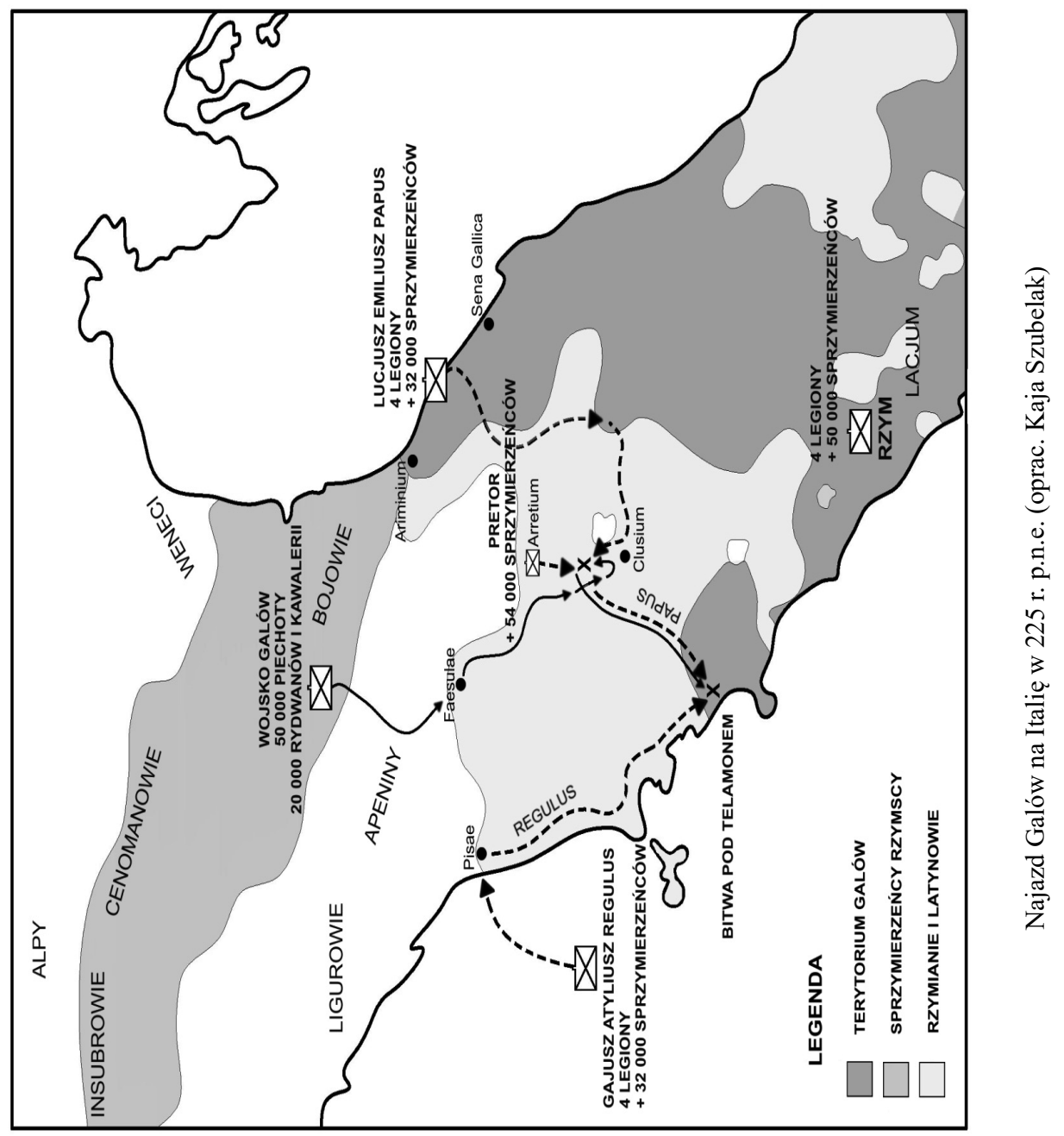

